\title{
Retention of metals in periprosthetic tissues of patients with metal-on-metal total hip arthroplasty is reflected in the synovial fluid to blood cobalt transfer ratio in the presence of a pseudotumour
}

\author{
Tomi Nousiainen ${ }^{1,2^{*}+}$ (D) Sanna Palosaari ${ }^{1+}$, Sirpa Peräniemi ${ }^{3}$, Arja Tervahauta ${ }^{4}$, Jaakko Niinimäki ${ }^{5}$,
} Juhana Leppilahti ${ }^{2}$ and Petri Lehenkari ${ }^{1,2}$

\begin{abstract}
Background: Modern metal-on-metal (MOM) arthroplasties were performed for over a decade before alarming reports of adverse metal reactions dramatically reduced their use. Failures are seen more often with high-wearing implants, but also well-positioned components with more favourable wear patterns can cause problems. There are no specific clinical indicators that could help us to predict the prognosis of these implants. For this reason, we still need more information on the effect of underlying factors that contribute to this process.

Methods: In this prospective cohort study, we investigated how cup orientation and type of pseudotumour determined by the Hart classification effect the distribution of metals in blood, synovial fluid and tissues surrounding the metal-on-metal hip prosthesis in revision surgery patients. One thousand two hundred twenty-nine metal-on-metal hip patients were screened and of those, 60 patients that had a revision surgery due to adverse metal reaction were included. Whole blood, synovial fluid and synovial/pseudotumour tissue samples were analysed for metal ion concentrations (Co, $\mathrm{Cr}$, Mo and Ti).

Results: The lowest metal concentrations were found when both cup anteversion and inclination were optimal, and the highest when both were suboptimal. Suboptimal anteversion alone raised $\mathrm{Cr}$-ion concentrations more than suboptimal inclination. The concentrations of metals in blood, synovial fluid or synovial soft tissue were the same in patients with and without a pseudotumour, but the relative transfer percentage of cobalt from synovial fluid to blood was higher in patients with a pseudotumour.

(Continued on next page)
\end{abstract}

\footnotetext{
* Correspondence: tomi.nousiainen@ppshp.fi

${ }^{\dagger}$ Tomi Nousiainen and Sanna Palosaari contributed equally to this work.

${ }^{1}$ Medical Faculty, Cancer and Translational Medicine Research Unit, University of Oulu and Medical Research Center, Oulu University Hospital, P.O. Box 5000, 90014 Oulu, Finland

${ }^{2}$ Division of Orthopaedic Surgery, Oulu University Hospital, Oulu, Finland

Full list of author information is available at the end of the article
}

(c) The Author(s). 2020 Open Access This article is licensed under a Creative Commons Attribution 4.0 International License, which permits use, sharing, adaptation, distribution and reproduction in any medium or format, as long as you give appropriate credit to the original author(s) and the source, provide a link to the Creative Commons licence, and indicate if changes were made. The images or other third party material in this article are included in the article's Creative Commons licence, unless indicated otherwise in a credit line to the material. If material is not included in the article's Creative Commons licence and your intended use is not permitted by statutory regulation or exceeds the permitted use, you will need to obtain permission directly from the copyright holder. To view a copy of this licence, visit http://creativecommons.org/licenses/by/4.0/ The Creative Commons Public Domain Dedication waiver (http://creativecommons.org/publicdomain/zero/1.0/) applies to the data made available in this article, unless otherwise stated in a credit line to the data. 


\begin{abstract}
(Continued from previous page)
Conclusions: The implant orientation alone does not explain the metal concentrations found in tissues or distribution of metals between different tissues. The accumulation of metals in periprosthetic soft tissues increase the total metal load, and in the presence of a pseudotumour this is reflected in the transfer ratio of Co from synovial fluid to the blood. The total metal load of the pseudotumour tissue should be defined in future studies to determine if this will provide new insights for clinical practice.
\end{abstract}

Keywords: Metal-on-metal hip, Pseudotumour, Adverse reaction, Metals, Revision surgery

\section{Background}

During recent years there has been extensive research on metal-on-metal (MOM) hip prostheses because of the increasing awareness of adverse reactions. The clinical aspects of MOM implants have been studied widely and the follow-up protocols and clinical practices have evolved through years of research and clinical experience. There are studies which explain these reactions by local toxic and hypersensitivity reactions to wear particles [1-6]. Implant malpositioning has been suggested as the cause for the rise in blood metal ion levels [7] and implant properties as the reason for wear $[8,9]$. Adverse reactions have also been detected when the implant is in an optimal position [10]. The properties and size of wear particles from the articular surface or taper junctions have been found to differ on a nanometer scale, and it is suggested [11] that particle properties could be more important than total particle burden in the occurrence and severity of adverse tissue reactions. Still, there is concern about possible systemic toxicity caused by these wear particles that are disseminated into the periprosthetic tissues and also to remote locations in the body [12].

The common denominator for these studies is that adverse reactions are found more often than anticipated, and clinical manifestations vary [13-15]. The awareness of implant reactions might partially explain the rise, but there is substantial evidence [16-20] that this is a real clinical phenomenon, although some of these reactions can be asymptomatic. It is unsettling that there are no specific clinical indicators that could predict the prognosis of these prostheses. It is also unknown why so many patients with abnormal metal reactions remain clinically painless until devastating soft tissue lesions progress and cause limping and disability [21].

The terminology of these adverse reactions varies (ALVAL, aseptic lymphocyte-dominated vasculitisassociated lesion; ARMD, adverse reaction to metal debris; ALTR, adverse local tissue reaction) but the term pseudotumour is universally used. Different follow-up protocols are advised, but individual parameters like blood ions, plain radiographs or clinical symptoms in isolation can be misleading and should therefore be used in combination [22]. It has been shown that the best accuracy is achieved by measuring blood ions and MARS
MRI (metal artifact reduction sequence magnetic resonance imaging) regularly [23]. Even though implantation of MOM prostheses has almost ceased, we must bear in mind the economical aspect of follow-ups, considering the immense number of patients with these implants globally. For this reason, we need more information on the mechanical, physiological and cellular events behind the adverse effects.

The aim of this study is to describe the effect of acetabular component angles and pseudotumour formation on the blood metal ion levels, one of the clinical indicators of implant wear.

\section{Methods \\ Patients}

This prospective cohort study was approved by the Ethics Committee of Oulu University Hospital, Oulu, Finland, and complies with the Declaration of Helsinki. All patients gave their written informed consent. A flow chart of inclusion criteria of this study is shown in Fig. 1 and the detailed screening protocol is presented in Supplement S1.

Between April 2013 and December 2014, a total of 1286 patients with MOM hip arthroplasty were screened in Oulu University hospital. Of those, 429 patients were symptomatic or had ion levels more than $0.005 \mathrm{ppm}$ $(5 \mu \mathrm{g} / \mathrm{l})$. These were further examined by MARS MRI. A total of 69 hips were revised between September 2013 and March 2015, due to the results of MARS MRI, patient symptoms and blood ion levels. The study began after the first nine revisions, and a total of 60 patients were included to the study.

Sixty primary total hip arthroplasties were performed between March 1997 and May 2011 (Table 1.). The indication for total hip arthroplasty was end-stage osteoarthritis $(\mathrm{OA})$ in $41(68.3 \%)$ cases, rheumatoid arthritis in 9 $(15 \%)$ cases, trauma in $6(10 \%)$ cases and secondary OA in $4(6.7 \%)$ cases. The mean age of patients at the time of primary hip implantation was 55 years (SD 10.4) and at the time of MOM revision 63 years (SD 9.8). Several different primary implants (Table 2) were used, but the most common was the Bimetric/M2A38 combination. The mean in-situ time of MOM implants was 86 months (SD 24.1). 


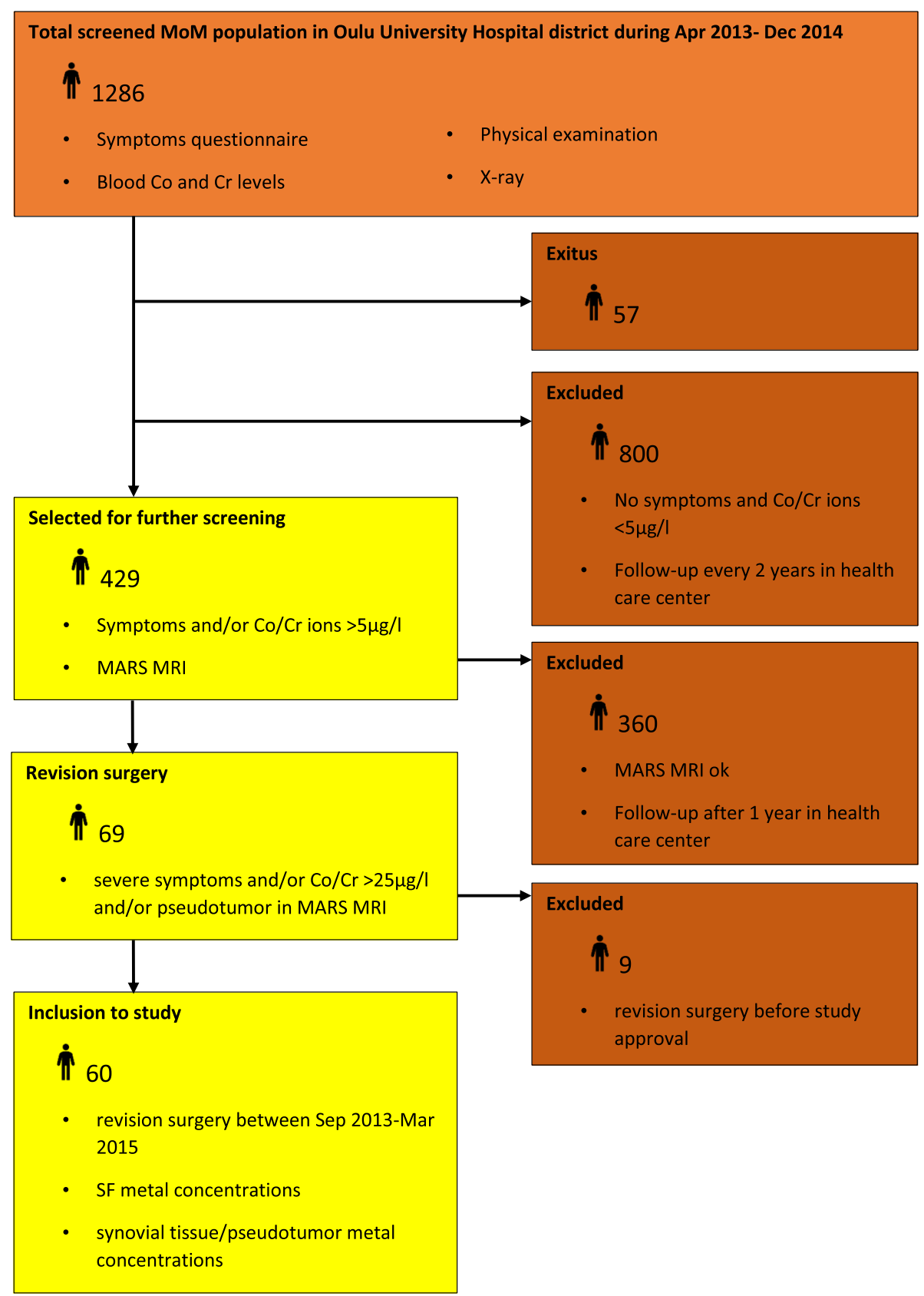

Fig. 1 Inclusion criteria

MARS MRI was performed on 57 (95\%) patients. There were three patients for whom MRI was not performed, one patient had a cardiac pacemaker, one patient had a dorsal root nerve stimulator and one patient had severe symptoms requiring revision. Clinical findings during revision were abnormal in all those three cases. MRI findings were evaluated using the classification described by Hart [10, 24]. Abnormal MRI findings were Hart 1 in 8 (14\%) cases, Hart 2A in 14 (24.6\%) cases, Hart $2 \mathrm{~B}$ in $12(21.1 \%)$ cases and Hart 3 in 9
(15.8\%) cases. MRI findings were normal on 14 (24.6\%) cases. Patients who had more than one tumour (n 20) were classified by the more severe grade.

Version and inclination of acetabular components were measured from standard pelvic $\mathrm{x}$-ray pictures which were obtained from our digital Picture Archiving and Communication System (PACS). One of the authors (TN) made all the measurements. Inclination was measured from standard anteroposterior pelvic X-rays using a digital angle meter and reference lines were drawn 
Table 1 Demographic data of included patients

\begin{tabular}{|c|c|}
\hline Variables & Value \\
\hline \multicolumn{2}{|l|}{ Gender } \\
\hline Female & $35(58 \%)$ \\
\hline Male & $25(42 \%)$ \\
\hline \multicolumn{2}{|l|}{ Side } \\
\hline Right hip & $41(68 \%)$ \\
\hline Left hip & $19(32 \%)$ \\
\hline \multicolumn{2}{|c|}{ Age at the time of revision, years } \\
\hline Mean & 63 (SD 9.8) \\
\hline Range & Min $30-\max 80$ \\
\hline \multicolumn{2}{|c|}{ Implant in-situ time, months } \\
\hline Mean & 86 (SD 24.1) \\
\hline Range & Min $29-\max 132$ \\
\hline \multicolumn{2}{|l|}{$\mathrm{BMl}, \mathrm{kg} / \mathrm{m}^{2}$} \\
\hline Mean & 28.9 (SD 4.9) \\
\hline Range & Min $17.5-\max 38.6$ \\
\hline \multicolumn{2}{|l|}{ Weight, kg } \\
\hline Mean & 80.9 (SD 16.4) \\
\hline Range & Min $46-\max 130$ \\
\hline \multicolumn{2}{|c|}{ Cup anteversion, degrees } \\
\hline Mean & 21.6 (SD 10.9) \\
\hline Range & Min $-7-\max 46$ \\
\hline \multicolumn{2}{|c|}{ Cup inclination, degrees } \\
\hline Mean & 49.9 (SD 9.5) \\
\hline Range & Min $26-\max 70$ \\
\hline \multicolumn{2}{|l|}{ WB Co, $\mu \mathrm{g} / \mathrm{l}$} \\
\hline Mean & 29.6 (SD 37.7) \\
\hline Range & Min $0.8-\max 193.2$ \\
\hline \multicolumn{2}{|l|}{ WB Cr, $\mu \mathrm{g} / \mathrm{l}$} \\
\hline Mean & 13.4 (SD 16.3) \\
\hline Range & Min 0.5 - max 95.9 \\
\hline \multicolumn{2}{|c|}{ Oxford Hip Score, points } \\
\hline Mean & 35.8 (SD 13.4) \\
\hline Range & Min $12-\max 48$ \\
\hline
\end{tabular}

from the lowest point of the pelvic rami and edges of the acetabular component. This is found to be a reliable and accurate method [25]. Version was measured from lateral cross-Table X-rays with the same method and using reference lines from the edges of the acetabular component and a line perpendicular to the horizontal plane. This method is described by Woo and Morrey [26].

\section{Revision surgery}

All revisions were carried out at Oulu University Hospital. Posterior approach was used in all revisions, and when removal of a well-fixed femoral component was needed, an extended proximal femoral osteotomy was used as described by Younger [27]. An average of three culture samples were taken (range 1-6) from the hip joint to rule out infection. In 57 cases all cultures were clean and the remaining three patients had not had previous infection. In two cases we found one positive enrichment culture after 10 days, one patient with Propionibacterium acnes in 1/3 cultures and another patient with Staphylococcus warneri in 1/4 cultures. Neither of these patients had infection before, during or after the MOM revision. These cultures were deemed to have been contaminations. One patient without previous signs of infection gave two positive enrichment cultures (10 days) out of five with Staphylococcus capitis. He developed a clinical infection after a few weeks latent time. The infection was treated with revision surgery and antibiotics.

During revisions a joint fluid aspirate was taken (synovial fluid, SF, n 53) before opening the deep fascia. There were 7 cases with a dry joint cavity. Biopsies from the pseudotumour tissue, or from neo-synovium if a pseudotumour was not present (soft tissue, ST, n 60), were taken after opening the joint. Two soft tissue samples were not available for metal analyses. Whole blood (WB, n 60) samples were also collected and analysed.

The clinical findings during revision varied greatly, ranging from a tight fibrous capsule around the hip joint to a bulky, sack-like pseudotumour around the hip. The appearance of joint fluid ranged from greyish to black metallic to milky white. In two cases femoral stems were loose. Acetabular components were loose in five cases, all of which were M2A38. In four patients, joint fluid contained rice-like debris. Taper of the femoral component was mentioned to be good in $18(31,6 \%)$ cases, discolored, dark or tarnished in $29(50,9 \%)$ cases and worn in 4 (7\%) cases. Total hip revision was done in nine (15\%) cases including all HRAs (hip resurfacing arthroplasties) and the remaining $51(85 \%)$ cases were cup revisions.

\section{Metal analysis}

For whole blood $\mathrm{Co}$ and $\mathrm{Cr}$ analyses, samples were collected from the patient's antecubital vein in heparincontaining trace element blood tubes. To avoid metal contamination from the needle, the standard protocol for blood sample collection for these analyses included rinsing of the collection needle by collecting one spare tube prior to actual sample collection. Quantification of blood $\mathrm{Co}$ and $\mathrm{Cr}$ concentrations were conducted by Vita Laboratoriot using the clinically accredited inductively coupled plasma mass spectrometry (ICP-MS) method.

A soft tissue sample adjacent to the synovial cavity, or if present from the synovial pseudotumour, was 
Table 2 Different implant types

\begin{tabular}{lll}
\hline Implant type & Number of implants & Head size (mm) \\
\hline Bimetric/M2A38 (Biomet) & 38 & 38 \\
Bimetric M2A Magnum/Recap (Biomet) & 11 & Median 46 (40-54) \\
CDH/M2A38 (Biomet) & 1 & 38 \\
Integral/M2A38 (Biomet) & 1 & 38 \\
Profemur T/Conserve (Wright Medical) & 1 & 42 \\
ML Taper/Durom (Zimmer) & 1 & 44 \\
Corail/Pinnacle (DePuy) & 1 & 36 \\
Anthology/R3 (Smith\&Nephew) & 1 & 40 \\
Synergy/BHR Modularis (Smith\&Nephew) & 1 & 54 \\
Taperloc M2A Magnum/Recap (Biomet) & 1 & $\mathrm{~N} / \mathrm{A}$ \\
Recap resurfacing (Biomet) & 2 & 42 and 48 \\
BHR resurfacing (Smith\&Nephew) & 1 & 46 \\
\hline
\end{tabular}

collected into a dry container and frozen at $-80{ }^{\circ} \mathrm{C}$ until analysed. For metal analysis, $0.1 \mathrm{~g}$ samples were weighed with a Mettler Toledo MX5 (readability $0.1 \mathrm{mg}$ ), placed in a teflon digestion vessel and $8.0 \mathrm{ml} \mathrm{HNO}_{3}$ (TraceMetal Grade, Fisher Chemical, A509-P1) was added. The samples were microwave digested using a MARS 6 iWave instrument and an Animal Tissue method. After the digestion, the samples were diluted to $20 \mathrm{ml}$ with deionized water (USF Elga Maxima). The concentrations of the analytic elements were measured with an ICP-MS (Perkin Elmer NexION 350D) using the kinetic energy discrimination (KED) mode. The instrument was calibrated with multielement standards (TraCERT Periodic table mix 1 for ICP, Sigma-Aldrich, 92,091 and TraCERT Periodic table mix 2 for ICP, Fluka, 41,135) and a single element standard for $\mathrm{Hg}$ (CertiPUR, Merck, 170, 226). Synovial soft tissue samples from three patients undergoing primary hip replacement surgery were used as controls reflecting metal concentrations of synovial soft tissue that has not been exposed to a metal-implant.

For metal analyses of synovial fluid $(100 \mu \mathrm{l}), 2.0 \mathrm{ml}$ $\mathrm{HNO}_{3}$ (TraceMetal Grade, Fisher Chemical, A509-P1) was added and the samples were digested using ultrasound assisted acid digestion. After $15 \mathrm{~min}$ the digestion sample was diluted to $5 \mathrm{ml}$ with de-ionized water (USF Elga Maxima). The concentrations of the analytic elements were measured with ICP-MS (Perkin Elmer NexION 350D) using the KED mode. The instrument was calibrated with multielement standards (TraCERT Periodic table mix 1 for ICP, Sigma-Aldrich, 92,091 and TraCERT Periodic table mix 2 for ICP, Fluka, 41,135) and a single element standard for $\mathrm{Hg}$ (CertiPUR, Merck, 170, 226). Synovial fluid samples from three patients undergoing primary hip replacement surgery were used as controls reflecting metal concentrations of synovial soft tissue that has not been exposed to a metal-implant.
The distribution of metals was analysed in relation to the presence or absence of pseudotumours. The SF and ST $\mathrm{Cr}$ and Co concentrations were proportioned to blood $\mathrm{Cr}$ and Co concentrations by dividing the WB concentration by the SF or ST concentration and converting these to percentages.

\section{Statistical analyses}

SPSS for Windows (IBM Corp. Released 2018. IBM SPSS Statistics for Windows, Version 25.0. Armonk, NY: IBM Corp.) was used for data analysis. For total metal concentrations the mean values (with standard deviation) are reported. A non-parametric Kruskal-Wallis test for independent samples was used for the evaluation of differences in metal concentrations between groups defined by implant cup angles (anteversion optimal/inclination optimal, AO/IO; anteversion optimal/inclination suboptimal, AO/IS; anteversion suboptimal/inclination optimal, AS/IO; anteversion suboptimal/inclination suboptimal, AS/IS) and pseudotumour type (no tumour, Hart 1, Hart 2A, Hart 2B, Hart 3). The Mann-Whitney test was used for evaluation of differences between metal concentrations (WB, SF and ST Co and $\mathrm{Cr}$ ) and between percentual transfer ratios from SF or ST to blood in patients with or without a pseudotumour. The results are given as median with 25 th-75th percentiles. $P$-values were adjusted by the Bonferroni correction for multiple tests and the values $<0.05$ were considered statistically significant.

\section{Results}

\section{Quantification of selected metal ions}

Synovial fluid and synovial soft tissue samples were measured for Co, Cr, Mo and Ti. Only Co, Cr and Mo were found consistently in samples and thus were further analysed statistically. Titanium concentrations exceeding the 
mean $+2 \mathrm{SD}$ of controls were found in 18 synovial fluid and 13 soft tissue samples (Supplement S2).

The metal concentrations in the studied tissues are presented in Fig. 2. In blood, the Cr concentration median was 0.0053 (25-75 percentile range 0.022$) \mathrm{ppm}$ and Co median 0.0079 (25-75 percentile range 0.046$) \mathrm{ppm}$. No other metals were measured from these samples. In synovial fluid of MOM patients, $\mathrm{Cr}$ concentrations were 312-fold higher and Co concentrations 115-fold higher than in their blood. In controls, metal concentrations were negligible. $\mathrm{Cr}$ concentrations of MOM patients' soft tissues were 10,476-fold and Co concentrations 1325-fold higher than in their blood.

We tested but did not find any statistically significant differences in metal ion levels (whole blood, synovial fluid, synovial tissue/pseudotumour) in relation to BMI, weight, height, implant type, implant head size or the implant in situ time.

\section{Effect of implant angles on metal concentrations}

We found a great diversity regarding the orientation of acetabular components. Only one third of cups were implanted correctly in the safe zone as defined by Lewinnek, anteversion $15+/-10^{\circ}$ and inclination $40+/-10^{\circ}$ [28] (Fig. 3). Fifty-five percent (n 33) of implants had correct anteversion and 55\% (n 33) had correct inclination. Cup orientation was correct in both planes in $33.3 \%$ (n 20). 20\% (n 12) of cups were out of the safe zone in both planes. Most (n 16/21) of those patients who had low $\leq 0.005 \mathrm{ppm}(\leq 5 \mu \mathrm{g} / \mathrm{l})$ WB Co and WB Cr concentrations had poor cup orientation either in both planes or only poor anteversion or inclination. Inside the safe zone 15 of 20 patients had elevated $\geq 0.005 \mathrm{ppm}$ ( $\geq$ $5 \mu \mathrm{g} / \mathrm{l}) \mathrm{WB}$ Co and/or Cr ions.

Metal concentrations in all tissues were lowest when both anteversion and inclination angle were in the optimal range and highest when both were suboptimal (Fig. 4 and Table 3) Suboptimal anteversion angle alone raised $\mathrm{Cr}$ concentrations in all tissues more than suboptimal inclination alone (Fig. 4a, d, g; Fig. 5; Supplements S3 and S4). Statistically significant differences between groups were found between suboptimal inclination $(\mathrm{AO} / \mathrm{IS})$ and malorientation in both planes (AS/IS) (Table 3). When the cup was malorientated in both planes, the $\mathrm{Cr}$ concentration increased approximately 99-fold in SF $(p=0.015), 14$-fold in ST $(p=0.016)$ and 8-fold in WB $(p=0.018)$; Co increased 13-fold in SF $(p=0.006)$ (Fig. 4b) and in WB $(p=0.032)$ (Fig. 4h) and Mo increased 32-fold in SF ( $p=0.008)$ (Fig. 4c) and 16-fold in ST $(p=0.027)$ (Fig. 4f). The metal concentrations were also significantly increased when suboptimal orientation in both planes (AS/IS) were compared to optimal orientation in both planes $(\mathrm{AO} / \mathrm{IO})$. Here the increase of Co concentration was 9-fold in SF $(p=0.030), 17$-fold in ST $(p=0.011)$ (Fig. 4b, e, f). The increase of Mo concentration was 16-fold in SF $(p=0.037)$ and 22 -fold in ST $(p=0.017)$ (Fig. 4c, f) and $\mathrm{Cr}$ concentration increased 28-fold in ST $(p=0.017)$ (Fig. 4d).

\section{Effect of pseudotumour on distribution of metals}

The concentration of metals ( $\mathrm{Cr}$ and $\mathrm{Co})$ in different tissues (WB, SF, ST) did not differ statistically significantly between patients with or without a pseudotumour (Supplementary file S5). The percentage of Co transferred from SF to WB was 1.7-fold higher in patients with than without a pseudotumour $(p=0.039)$ (Table 4$)$. No

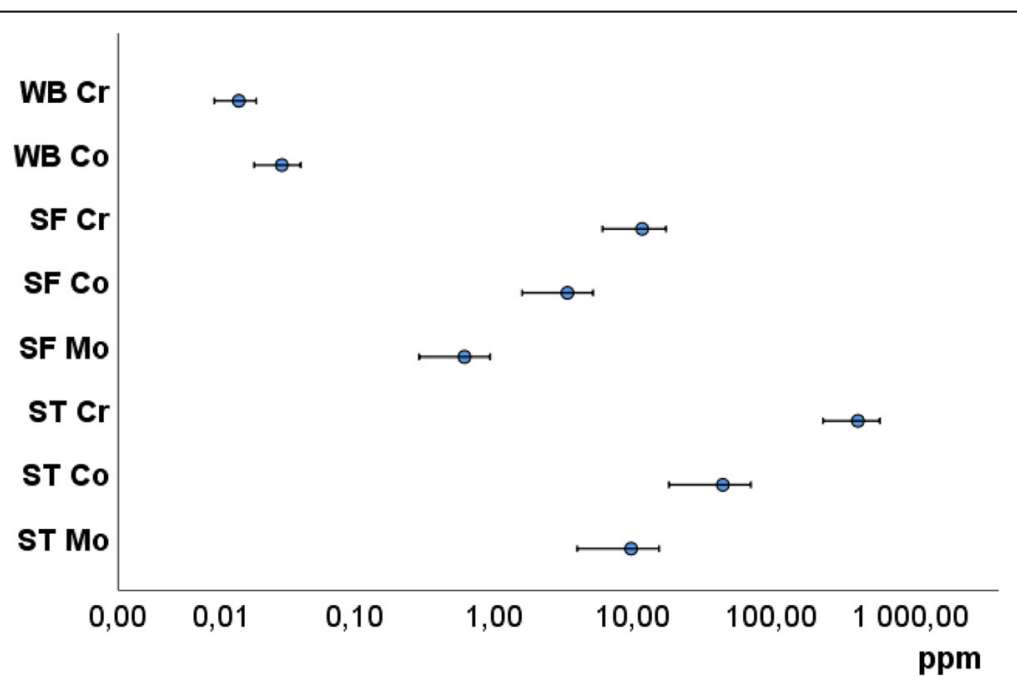

Fig. 2 Metal concentrations in whole blood (WB), synovial fluid (SF) and synovial soft tissue (ST). The highest local metal concentrations were found in the synovial soft tissue followed by synovial fluid and blood. The distribution of chromium was different between tissues showing local accumulation of chromium in the synovial soft tissue 


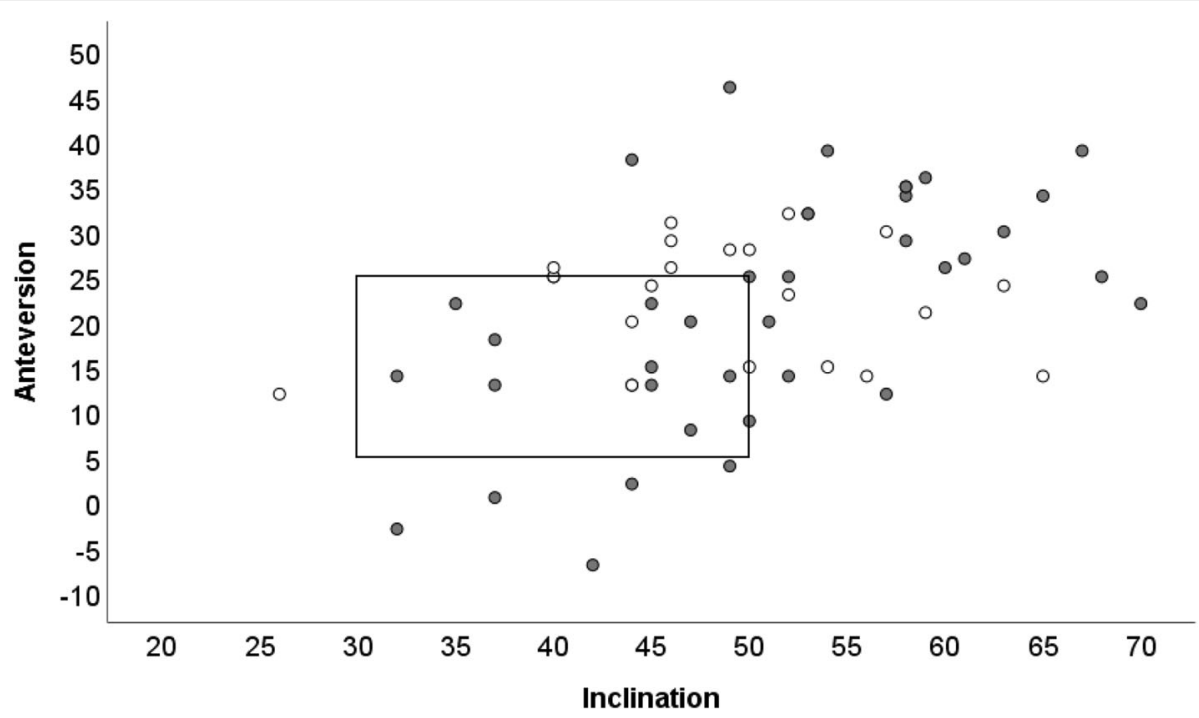

Fig. 3 The distribution of anteversion and inclination angles in the MOM revision patients included in this study. Lewinnek safe zone [28] is indicated by a square and the patients with WB Cr and Co concentrations $\leq 0.005 \mathrm{ppm}(5 \mu \mathrm{g} / \mathrm{l})$ are marked with white dots and patients with $\mathrm{Cr}$ and/or Co concentrations $\geq 0.005$ ppm $(5 \mu \mathrm{g} / \mathrm{l})$ are marked with gray dots
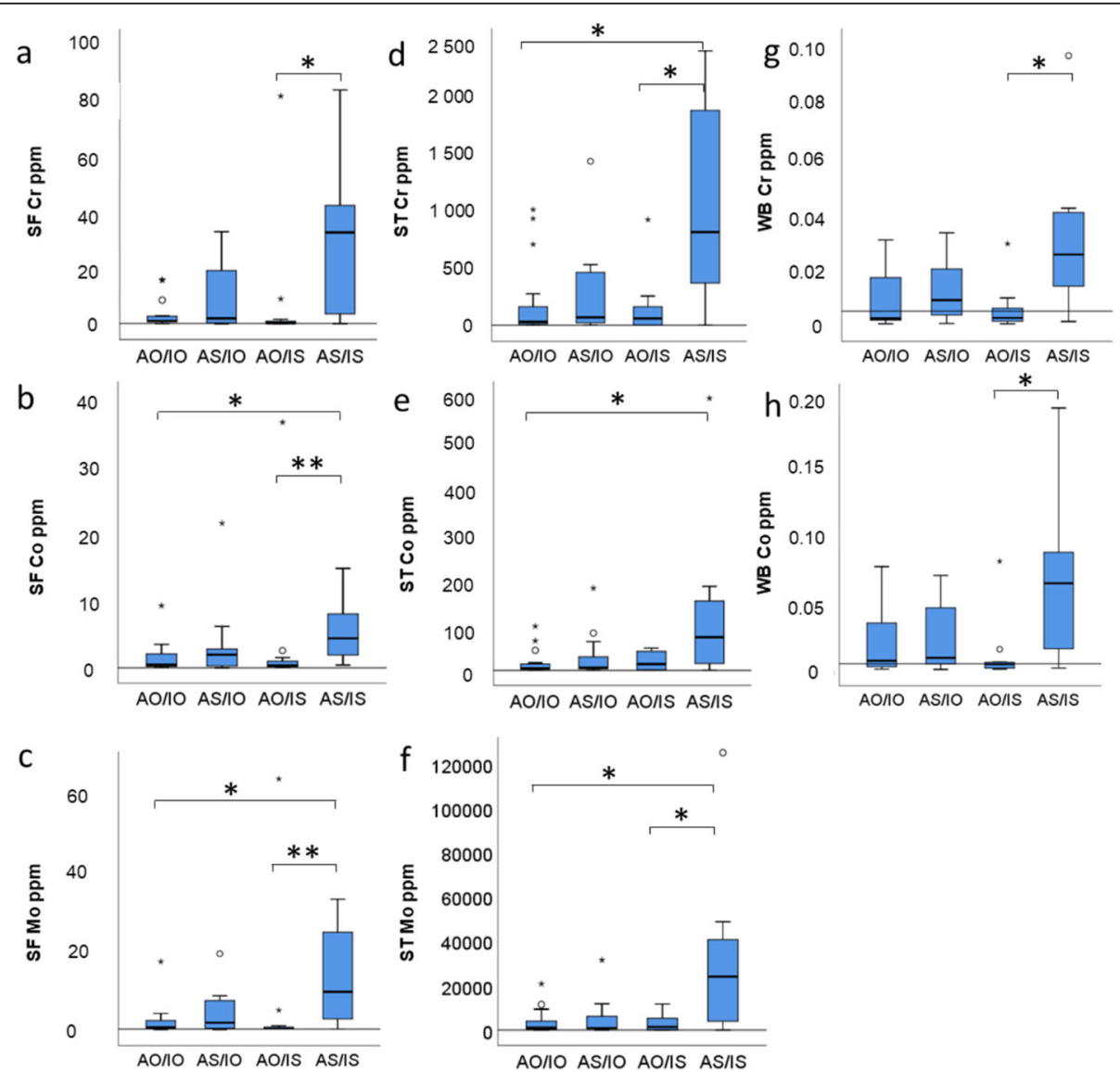

Fig. 4 Effect of anteversion and inclination angles on metal concentrations. Mean + 2SD of controls is indicated by a horizontal line for synovial fluid (SF) and soft tissue (ST) samples. AO, anteversion optimal; AS, anteversion suboptimal; IO, inclination optimal; IS, inclination suboptimal. For SF and ST: AO/IO n 15, AS/IO n 13, AO/IS n 11, AS/IS n 11; For WB: AO/IO n 19, AS/IO n 15, AO/IS n 13, AS/IS n 13; * $p<0.05,{ }^{* *} p<0.01$ 
Table 3 Distribution of metals (median with 25th-75th percentiles) in tissues by anteversion and inclination angles

\begin{tabular}{|c|c|c|c|c|}
\hline & AO/IO (n 20) & AS/IO (n 13) & AO/IS (n 13) & AS/IS (n 14) \\
\hline Synovial fluid & (ppm) & (ppm) & (ppm) & (ppm) \\
\hline $\mathrm{Cr}$ & 1.10 & 2.01 & 0.33 & 32.78 \\
\hline$(p=0.020)^{*}$ & $(0.77-2.85)$ & $(0.35-20.35)$ & $(0.18-1.67)$ & $(4.91-49.24)$ \\
\hline Co & 0.46 & 1.95 & 0.33 & 4.36 \\
\hline$(p=0.006)^{* *}$ & $(0.23-2.95)$ & $(0.25-3.08)$ & $(0.16-1.54)$ & $(2.40-9.24)$ \\
\hline Mo & 0.06 & 0.18 & 0.03 & 0.95 \\
\hline$(p=0.008)^{* *}$ & $(0.03-0.32)$ & $(0.03-0.73)$ & $(0.02-0.10)$ & $(0.34-2.78)$ \\
\hline \multicolumn{5}{|l|}{ Soft tissue } \\
\hline $\mathrm{Cr}$ & 30.00 & 70.00 & 60.00 & 830.00 \\
\hline$(p=0.013)^{*}$ & $(10.00-280.00)$ & $(15.00-505.00)$ & $(0.00-180.00)$ & $(552.50-2115.00)$ \\
\hline Co & 4.30 & 5.50 & 13.60 & 72.70 \\
\hline$(p=0.012)^{*}$ & $(2.40-16.70)$ & $(2.25-46.30)$ & $(0.600-43.20)$ & $(13.52-179.95)$ \\
\hline Mo & 1.10 & 1.00 & 1.50 & 24.20 \\
\hline$(p=0.012)^{*}$ & $(0.40-5.20)$ & $(0.45-7.95)$ & $(0.10-5.70)$ & $(4.82-45.42)$ \\
\hline \multicolumn{5}{|l|}{ Whole blood } \\
\hline $\mathrm{Cr}$ & 0.002 & 0.009 & 0.003 & 0.025 \\
\hline$(p=0.024)^{*}$ & $(0.001-0.023)$ & $(0.003-0.021)$ & $(0.001-0.007)$ & $(0.019-0.042)$ \\
\hline Co & 0.007 & 0.009 & 0.005 & 0.064 \\
\hline$(p=0.029)^{*}$ & $(0.002-0.035)$ & $(0.004-0.047)$ & $(0.002-0.006)$ & $(0.022-0.097)$ \\
\hline
\end{tabular}

$p$-values from Kruskal-Wallis test, ${ }^{*} p<0.05$ and ${ }^{* *} p<0.01$

differences in the percentage of Co transferred from ST to $\mathrm{WB}$ or $\mathrm{Cr}$ transferred from SF or ST to WB were found (Table 4).

Patients with type 2A pseudotumours had lower overall metal concentrations in SF, ST and blood when compared to other groups. The levels of $\mathrm{Cr}$, Co and Mo in synovial fluid (Table 4. and Fig. 6a-c) were higher in patients without pseudotumours than in patients with pseudotumours. The metal concentrations in blood (Fig. $6 \mathrm{~g}, \mathrm{~h}$ ) followed the trend of the metal concentrations in the synovial fluid as $\mathrm{Cr}$ and $\mathrm{Co}$ concentrations were highest in patients without pseudotumours and lowest in patients with type $2 \mathrm{~A}$ and 3 pseudotumours. The distribution of metals in the soft tissue samples (Fig. 6d-f) differed from the synovial fluid and blood. The highest ST Cr concentrations were in patients with type 1 (4fold higher compared to no tumour) and type $2 \mathrm{~B}$ tumours (3-fold higher), followed by patients with type 3 tumours (2-fold higher), suggesting retention of $\mathrm{Cr}$ in the pseudotumour tissue (Fig. 6d). The distribution of
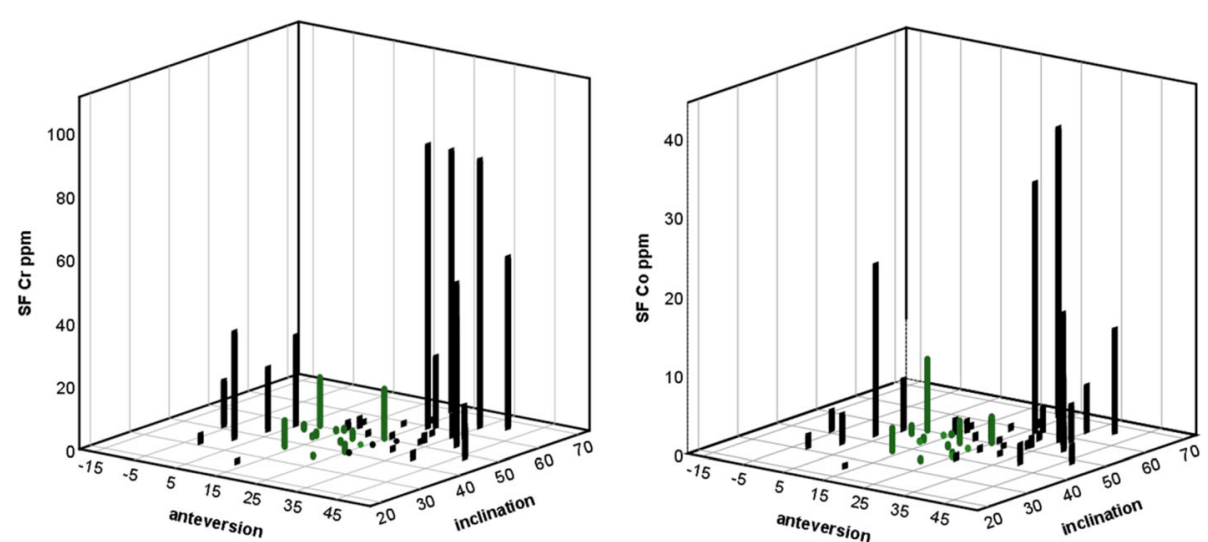

Fig. 5 3D graph showing concentration of synovial fluid $\mathrm{Cr}$ and $\mathrm{Co}$ in relation to anteversion and inclination angles. Cases with optimal implant angles are presented with green bars 
Table 4 The relative percentage (median with 25th-75th percentiles) of $\mathrm{Cr}$ and Co transferred from SF or ST to WB

\begin{tabular}{lll}
\hline & No tumour & Tumour \\
\hline WB/SF & \% & \% \\
Cr & $\mathbf{0 . 2 0 7}$ & $\mathbf{0 . 2 6 5}$ \\
$(p=0.304)$ & $(0.073-0.598)$ & $(0.160-0.592)$ \\
Co & $\mathbf{0 . 6 6 7}$ & $\mathbf{1 . 1 5 4}$ \\
$(p=0.039)$ & $(0.358-1.322)$ & $(0.683-2.003)$ \\
WB/ST & & \\
Cr & 0.003 & $\mathbf{0 . 0 0 5}$ \\
$(p=0.741)$ & $(0.002-0.032)$ & $(0.002-0.008)$ \\
Co & $\mathbf{0 . 0 6 6}$ & $\mathbf{0 . 0 7 1}$ \\
$(p=0.892)$ & $(0.021-0.427)$ & $(0.039-0.239)$ \\
\hline
\end{tabular}

Co and Mo in soft tissue (Fig. 6e, f) was different from $\mathrm{Cr}$, as the highest Co concentrations were found in patients with type 1 tumours (2-fold higher compared to no tumour) and up to 7 -fold lower in patients with other types of tumours. Mo concentration was highest in patients with type 1 tumours (4-fold higher compared to no tumour) and showed great variation between groups. Despite the observed differences in the metal concentrations between groups, the differences did not reach statistical significance (Table 5).

\section{Discussion}

In this study, we focused on the distribution of metals in periprosthetic tissues, synovial fluid and systemic circulation in relation to implant orientation and the presence or absence of a pseudotumour.

We first determined the overall metal load in the tissues. The most abundant metals found in the tissues of MOM patients were $\mathrm{Cr}$, Co and $\mathrm{Mo}$, as expected and reported in the literature. The processing of $\mathrm{Cr}$ and $\mathrm{Co}$ seems to differ in the body $[29,30]$; Co is removed from tissues and $\mathrm{Cr}$ shows retention. This is shown by the higher relative concentration of Co compared to $\mathrm{Cr}$ in blood, but in other tissues the relationship is the reverse. Some samples (synovial tissue n 13 and synovial fluid n 18) contained also elevated levels of titanium, which plausibly originates from the femoral taper. This hypothesis is supported by the fact that 18/33 cases of our study population with tarnished, discolored or worn femoral taper showed also elevated titanium levels in ST and/or SF.

Next, we looked at the effect of the implant orientation on the release of metal debris. We found great diversity regarding the orientation of acetabular components in the enrolled patients. Only $1 / 3$ of cups were implanted correctly in the safe zone as defined by Lewinnek [28]. This finding was in line with our previous work [31] where we found that cup orientation was
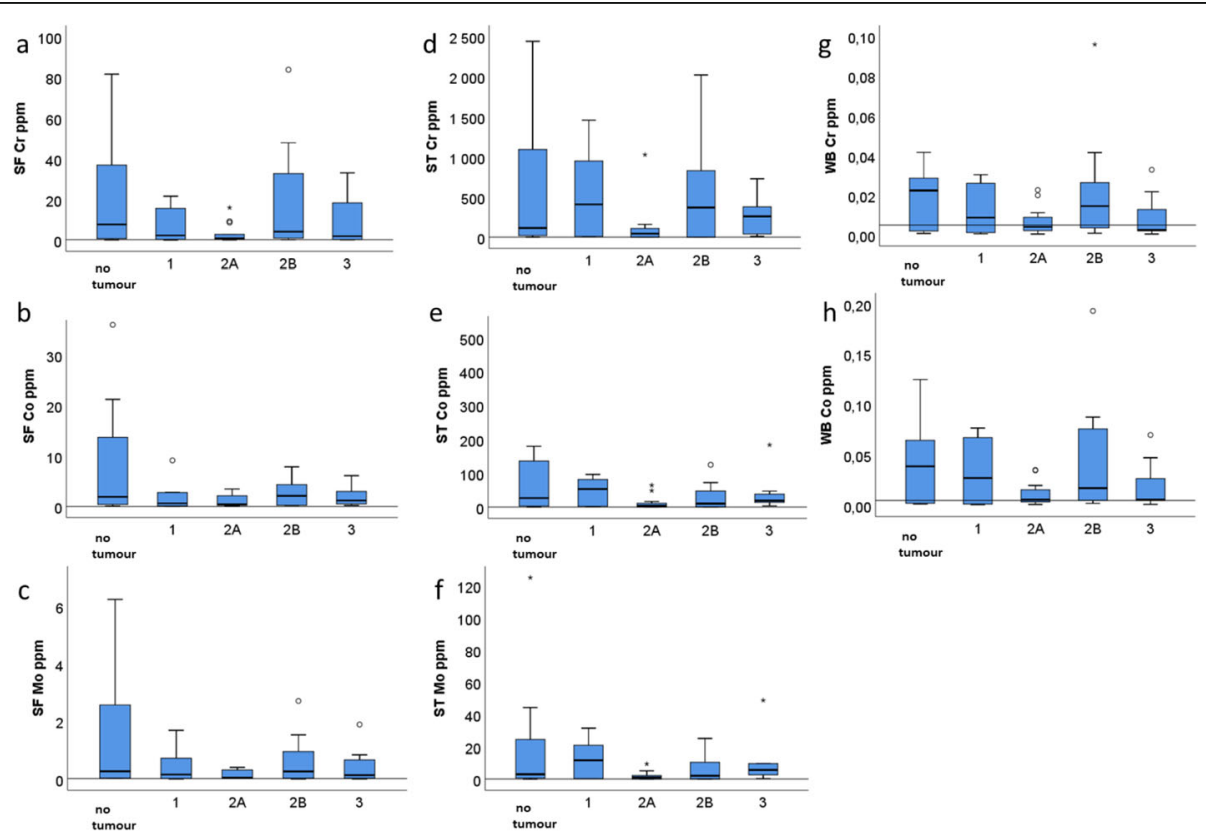

Fig. 6 Distribution of metals by Hart classification [24] of pseudotumours. The highest synovial fluid (SF) and whole blood (WB) metal concentrations were found in patients without a pseudotumour, and lowest in patients with a fluid-filled type 2A pseudotumour. The lowest whole blood metal concentrations were found in patients with type 3 pseudotumours. The lowest soft tissue (ST) metal concentrations were in patients with type $2 \mathrm{~A}$ tumour and highest in 1, 2B, and 3 tumours, suggesting retention of metals in the pseudotumour tissue. SF: no tumour $n$ 13, 1 n 6, 2A n 14, 2B n 10, 3 n 7; ST: no tumour n 12, 1 n 8, 2A n 14, 2B n 12, 3 n 9; WB: no tumour n 14, 1 n 8, 2A n 14, $2 B$ n 12,3 n 9. Reference line is set to mean $+2 \mathrm{SD}$ of controls for SF and ST and to $0.005 \mathrm{ppm}(5 \mu \mathrm{g} / \mathrm{l})$ for WB 
Table 5 Distribution of metals (median with 25th-75th percentiles) in tissues by Hart classification [24] of pseudotumours

\begin{tabular}{|c|c|c|c|c|c|}
\hline & No tumour (n 14) & Hart 1 (n 8) & Hart 2A (n 14) & Hart 2B (n 12) & Hart 3 (n 9) \\
\hline Synovial fluid & (ppm) & (ppm) & (ppm) & (ppm) & (ppm) \\
\hline $\mathrm{Cr}$ & 7.69 & 2.24 & 0.85 & 4.12 & 1.88 \\
\hline$(p=0.308)$ & $(0.51-37.02)$ & $(0.23-17.11)$ & $(0.29-4.22)$ & $(0.78-36.56)$ & $(0.22-27.62)$ \\
\hline Co & 1.91 & 0.62 & 0.38 & 2.11 & 1.18 \\
\hline$(p=0.202)$ & $(0.35-14.23)$ & $(0.07-4.38)$ & $(0.21-2.33)$ & $(0.24-4.66)$ & $(0.40-3.39)$ \\
\hline Mo & 0.28 & 0.16 & 0.06 & 0.27 & 0.14 \\
\hline$(p=0.327)$ & $(0.03-2.79)$ & $(0.02-0.97)$ & $(0.02-0.33)$ & $(0.03-1.10)$ & $(0.02-0.85)$ \\
\hline \multicolumn{6}{|l|}{ Soft tissue } \\
\hline $\mathrm{Cr}$ & 115.00 & 410.00 & 45.00 & 370.00 & 260.00 \\
\hline$(p=0.463)$ & (15.00-1172.50) & $(10.00-1077.50)$ & $(0.00-120.00)$ & $(0.00-1072.50)$ & $(20.00-470.00)$ \\
\hline Co & 26.85 & 53.50 & 3.80 & 10.40 & 19.40 \\
\hline$(p=0.197)$ & $(2.55-157.40)$ & $(2.10-85.48)$ & $(0.35-12.80)$ & $(0.50-53.88)$ & $(11.40-47.50)$ \\
\hline Mo & 3.05 & 11.75 & 1.10 & 2.10 & 5.70 \\
\hline$(p=0.328)$ & $(0.50-30.85)$ & $(0.38-23.55)$ & $(0.10-2.33)$ & $(0.10-13.93)$ & $(0.90-9.80)$ \\
\hline \multicolumn{6}{|l|}{ Whole blood } \\
\hline $\mathrm{Cr}$ & 0.022 & 0.008 & 0.004 & 0.015 & 0.003 \\
\hline$(p=0.142)$ & $(0.002-0.029)$ & $(0.001-0.027)$ & $(0.002-0.009)$ & $(0.003-0.030)$ & $(0.002-0.022)$ \\
\hline Co & 0.039 & 0.027 & 0.006 & 0.017 & 0.006 \\
\hline$(p=0.085)$ & $(0.002-0.073)$ & $(0.001-0.070)$ & $(0.003-0.017)$ & $(0.005-0.078)$ & $(0.005-0.047)$ \\
\hline
\end{tabular}

$p$-values from Kruskal-Wallis test

good in $41.5 \%$ of the total MOM population and only in $30.8 \%$ of patients with clinical indication for revision. Many studies $[7,8]$ have shown that poor component orientation increases the risk for an adverse reaction after hip arthroplasty. It has been suggested that inclination angle affects the blood metal concentration more than the anteversion angle [7]. Our data is in agreement with the hypothesis that the inclination angle shows a more linear relationship to blood metal concentrations compared to anteversion angle (Supplements S3 and S4), but mostly because the malposition in inclination does not settle on both sides of the Lewinnek's safe zone, as it does with anteversion. This means that there is a tendency for inclination that is too steep, but we seldom see cups that are too horizontal. Instead version is quite often either slightly retroverted or too steeply anteverted $[7,8,31]$. When both orientations were taken into account, we found that poor anteversion alone led to higher ion levels when compared to poor inclination alone (Figs. 4 and 5). The highest metal ion levels were found when the cup orientation was poor in both planes. Adverse reactions have been reported also in wellfunctioning and well-positioned hips [10, 24]. This can be partially due to the fact that not only the wear particles from the articulating surface, but also modular junctions between the components either on the femoral or acetabular side can contribute to particle load in soft tissues [32]. In the current study we did not measure the orientation of the femoral components, which affect the total component orientation and implant wear. This study shows that even with optimal component orientation, the whole blood $\mathrm{Co}$ and/or $\mathrm{Cr}$ ion levels may be elevated. Furthermore, whole blood $\mathrm{Co}$ and $\mathrm{Cr}$ ion levels can be low even though the implant orientation is poor. These observations highlight the inaccuracy of individual clinical parameters in predicting the implant survival.

Finally we focused on local factors that could affect the distribution of metals. In the presence of a pseudotumour the percentage of cobalt transferred from synovial fluid to whole blood was higher than in patients without a tumour. Since there were no differences between the groups in the SF or WB Co concentrations, there must be another source for the observed higher Co transfer. The pseudotumour retains some of the metals and adds to their transition to the circulation. It is known that cobalt is more readily transported to the blood and excreted in the urine, but chromium is accumulated in tissues [29, 33]. This is shown in the percentual transfer ratio of $\mathrm{Co}$ and explains why $\mathrm{Co}$ concentrations were higher than $\mathrm{Cr}$ in blood and the reverse was true for synovial fluid and soft tissue. This finding is important in the clinical perspective, since blood sampling is the standard method for ion level monitoring. In liquid samples (WB, SF) the measured concentration accurately reflects the absolute amount of metal in the tissue. In soft tissue biopsies, however, the sample may reflect only 
focal changes. We found interesting observational differences between the subgroups of pseudotumours. Soft tissue metal concentrations were higher in patients with type 1 , type $2 \mathrm{~B}$ or type 3 tumours and blood concentrations were highest in patients without a tumour (Fig. 6). Although there were differences in metal concentrations between the Hart classes, the differences were not statistically significant. Therefore, these pseudotumour subtype analyses should be interpreted as experimental and hypothesis generating. There are previous studies examining the correlation between whole blood, synovial fluid or synovial tissue metal ion levels and histological findings or cellular parameters. Reito et al. [34] studied the possible diagnostic utility of joint fluid metal ion measurement for histological findings, but neither cobalt nor chromium were found to have good predictive value. Lehtovirta et al. [35] found that whole blood, joint fluid and synovial tissue metal concentrations correlated poorly with histological findings. Yet, to our knowledge there are no previous studies examining the role of pseudotumours in the distribution of metals. In our opinion, this observation deserves to be investigated also in a larger cohort of patients. Previous studies, including our current study, examined only focal biopsies of the synovial/pseudotumour tissue, which may not reflect the total synovial metal load. The analysis of the whole pseudotumour, showing the total metal load, could give more accurate information and possibly show a stronger correlation with the blood concentrations.

There were also 14 patients without a radiologically detectable pseudotumour in this study. Clinical findings of the hip joint were abnormal in all these patients during the revision. Osteolysis was found in eight (57.1\%) patients and component loosening in three $(21.4 \%)$ patients. Most of the patients (71.4\%) had elevated blood metal ion levels and the vast majority $(78.6 \%)$ of cups were implanted poorly either in regard to anteversion or inclination or in both planes. Also, the metal concentrations in synovial fluid were highest in patients without a pseudotumour. It can be argued that these implants had increased wear rates because of poor implantation. Such elevated metal burden locally has cytotoxic effects which can cause tissue destruction. This can be evaluated with MARS MRI but diagnostics should not be limited only to ruling out pseudotumours.

There are some shortcomings in this study. First, the sample size (n 60) is relatively small and the patients with the most severe symptoms (n 9) were not included since they were operated before the study approval. Second, the selection of patients for this study was based solely on the clinical indications for revision. This led to a situation where the samples were from patients with different types of prostheses that can have different patterns of wear, which can increase variation in the results.
However, we did not find statistically significant differences in metal ion levels and the implant head size or implant type. Furthermore, the heterogeneity of the samples reflects the actual situation that is faced in orthopaedic practice. Third, we acknowledge the inaccuracy of plain radiographs compared to cross-sectional imaging when evaluating cup position. Yet, pelvic $\mathrm{x}$-rays are readily available and commonly used by orthopaedic surgeons. Also, there are several different classifications of pseudotumours and interobserver reliability of their identification varies. In a recent study [36], the Hart classification that we used was found to have better interobserver reliability than the classifications by Anderson [37] or Hauptfleisch [38].

These observations show the importance of systematic screening of MOM patients, including appropriate imaging and subsequent surgical intervention. Also, if revision surgery is performed the surrounding periprosthetic tissues should be thoroughly analysed histologically and biologically to provide more detailed information of this pathology.

\section{Conclusions}

This study, in agreement with earlier findings, shows the heterogeneous results of individual screening parameters, which should never be evaluated in isolation. High tissue metal load can be seen in patients with poorly implanted components. However, adverse tissue reactions are found even in patients with optimal implant orientation. While interpreting the results of our study, it should be noted that the study population was selected based on the need for revision surgery. Periprosthetic soft tissue shows retention of metals, increasing the patients' total metal load. This is reflected at least in the WB/SF Co percentual transfer ratio. Due to our small sample size it is hard to formulate any solid and generalized recommendations, but multidisciplinary screening of these patients is mandatory. Future studies with thorough analysis of periprosthetic soft tissues may be able to reveal new markers to better understand these destructive processes.

\section{Supplementary information}

Supplementary information accompanies this paper at https://doi.org/10. 1186/s12891-020-03636-0.

\section{Additional file 1. Detailed screening protocol}

Additional file 2. Ti concentrations exceeding mean + 2SD of controls were found in $18 \mathrm{MOM}$ synovial fluid samples and in 13 soft tissue samples.

Additional file 3. Metal concentrations in synovial fluid (SF), soft tissue (ST) and whole blood (WB) in relation to anteversion angle.

Additional file 4. Metal concentrations in synovial fluid (SF), soft tissue (ST) and whole blood (WB) in relation to inclination angle. 
Additional file 5. Metal concentrations in synovial fluid (SF), soft tissue (ST) and whole blood (WB) in relation to presence or absence of a pseudotumour.

\section{Abbreviations}

ALTR: Adverse local tissue reaction; ALVAL: Aseptic lymphocyte-dominated vasculitis-associated lesion; AO: Anteversion optimal; ARMD: Adverse reaction to metal debris; AS: Anteversion suboptimal; BMI: Body mass index; HRA: Hip resurfacing arthroplasty; IO: Inclination optimal; IS: Inclination suboptimal; MARS MRI: Metal artifact reduction sequence magnetic resonance imaging; MOM: Metal-on-metal; PACS: Picture archiving and communication system; SF: Synovial fluid; ST: Synovial tissue; WB: Whole blood

\section{Acknowledgements}

We thank Ms. Tarja Huhta for expert technical assistance in sample collection and Mr. Pasi Ohtonen for statistical advice.

\section{Authors' contributions}

TN, JL and PL designed the study. TN collected samples and data, measured the cup angles and performed part of the controls and part of the revision surgeries. S Palosaari coordinated the analyses of samples and performed data analyses. S Peräniemi and AT performed synovial fluid and soft tissue metal analyses. TN and S Palosaari drafted the manuscript. JN evaluated the MRI scans. All authors participated in revision of the manuscript and read and approved the final manuscript.

\section{Funding}

This study was funded by a research grant from the Northern Finland Healthcare Support Foundation (TERTTU) and Finnish government special state support for research (VTR) (S Palosaari, TN and PL). Metal analyses in Kuopio were funded by ERDF projects A72184 and A72185 (2016-2018) Regional Council of Pohjois-Savo "Development of ICP-MS and IC systems for advanced elemental and ion analyses" (S Peräniemi and AT).

\section{Availability of data and materials}

All data generated or analysed during this study are included in this published article and its supplementary information files.

\section{Ethics approval and consent to participate}

This study was approved by the Ethics Committee of Oulu University Hospital, Oulu, Finland, reference number 34/2013, and complies with the Declaration of Helsinki. All patients gave their written informed consent before entering the study.

\section{Consent for publication}

Not applicable.

\section{Competing interests}

The authors declare that they have no competing interests.

\begin{abstract}
Author details
${ }^{1}$ Medical Faculty, Cancer and Translational Medicine Research Unit, University of Oulu and Medical Research Center, Oulu University Hospital, P.O. Box 5000, 90014 Oulu, Finland. 'Division of Orthopaedic Surgery, Oulu University Hospital, Oulu, Finland. ${ }^{3}$ University of Eastern Finland, School of Pharmacy, P.O. Box 1627, 70210 Kuopio, Finland. ${ }^{4}$ Department of Environmental and Biological Sciences, University of Eastern Finland, P.O. Box 1627, 70210 Kuopio, Finland. ${ }^{5}$ Division of Radiology, Oulu University Hospital, Oulu, Finland.
\end{abstract}

Received: 18 February 2020 Accepted: 7 September 2020 Published online: 12 September 2020

\section{References}

1. Jones DA, Lucas HK, O'Driscoll M, Price CH, Wibberley B. Cobalt toxicity after McKee hip arthroplasty. J Bone Joint Surg Br. 1975;57(3):289-96.

2. Evans EM, Freeman MA, Miller AJ, Vernon-Roberts B. Metal sensitivity as a cause of bone necrosis and loosening of the prosthesis in total joint replacement. J Bone Joint Surg Br. 1974;56-B(4):626-42.
3. Athanasou NA. The pathobiology and pathology of aseptic implant failure Bone Joint Res. 2016. https://doi.org/10.1302/2046-3758.55.BJR-2016-0086.

4. Campbell P, Ebramzadeh E, Nelson S, Takamura K, De Smet K, Amstutz HC. Histological features of pseudotumor-like tissues from metal-on-metal hips. Clin Orthop Relat Res. 2010. https://doi.org/10.1007/s11999-010-1372-y.

5. Grammatopoulos G, Pandit H, Kamali A, Maggiani F, Glyn-Jones S, Gill HS, Murray DW, Athanasou N. The correlation of wear with histological features after failed hip resurfacing arthroplasty. J Bone Joint Surg Am. 2013. https:// doi.org/10.2106/JBJS.L.00775

6. Willert H, Buchhorn GH, Fayyazi A, Flury R, Windler M, Köster G, Lohmann $\mathrm{CH}$. Metal-on-metal bearings and hypersensitivity in patients with artificial hip joints A clinical and histomorphological study. J Bone Joint Surg Am. 2005. https://doi.org/10.2106/JBJS.A.02039pp.

7. Hart AJ, Skinner JA, Henckel J, Sampson B, Gordon F. Insufficient acetabular version increases blood metal ion levels after metal-on-metal hip resurfacing. Clin Orthop Relat Res. 2011. https:/doi.org/10.1007/s11999-011-1930-y.

8. Langton DJ, Jameson SS, Joyce TJ, Webb J, Nargol AVF. The effect of component size and orientation on the concentrations of metal ions after resurfacing arthroplasty of the hip. J Bone Joint Surg Br. 2008. https://doi. org/10.1302/0301-620X.90B9.20785.

9. Nassif NA, Nawabi DH, Stoner K, Elpers M, Wright T, Padgett DE. Taper design affects failure of large-head metal-on-metal total hip replacements. Clin Orthop Relat Res. 2014. https://doi.org/10.1007/s11999-013-3115-3.

10. Matthies AK, Skinner JA, Osmani H, Henckel J, Hart AJ. Pseudotumors are common in well-positioned low-wearing metal-on-metal hips. Clin Orthop Relat Res. 2012. https://doi.org/10.1007/s11999-011-2201-7.

11. Xia Z, Ricciardi BF, Liu Z, von Ruhland C, Ward M, Lord A, Hughes L, Goldring SR, Purdue E, Murray D, Perino G. Nano-analyses of wear particles from metal-on-metal and non-metal-on-metal dual modular neck hip arthroplasty. Nanomedicine. 2017. https://doi.org/10.1016/j.nano.2016.11.003.

12. Bijukumar DR, Segu A, Souza JCM, Li X, Barba M, Mercuri LG, Jacobs JJ, Mathew MT. Systemic and local toxicity of metal debris released from hip prostheses: A review of experimental approaches. Nanomedicine. 2018. https://doi.org/10.1016/j.nano.2018.01.001.

13. Goldstein ZH, Estrera K, Levine BR. Taper failure after large-diameter metalon-metal Total hip Arthroplasty. Orthopedics. 2016. https://doi.org/10.3928/ 01477447-20160526-07.

14. Meyer H, Mueller T, Goldau G, Chamaon K, Ruetschi M, Lohmann CH. Corrosion at the Cone/Taper interface leads to failure of large-diameter metal-on-metal Total Hip Arthroplasties. Clin Orthop Relat Res. 2012. https:// doi.org/10.1007/s11999-012-2502-5.

15. Junnila M, Seppänen M, Mokka J, Virolainen P, Pölönen T, Vahlberg T, Mattila K, Tuominen EKJ, Rantakokko J, Äärimaa V, Itälä A, Mäkelä KT Adverse reaction to metal debris after Birmingham hip resurfacing arthroplasty. Acta Orthop. 2015. https://doi.org/10.3109/17453674.2014. 1004015.

16. Bolland BJRF, Culliford DJ, Langton DJ, Millington JPS, Arden NK, Latham JM High failure rates with a large-diameter hybrid metal-on-metal total hip replacement. J Bone Joint Surg Br. 2011. https://doi.org/10.1302/0301-620X. 93B5.26309.

17. Kwon Y, Ostlere SJ, McLardy-Smith P, Athanasou NA, Gill HS, Murray DW. "Asymptomatic" pseudotumors after metal-on-metal hip resurfacing arthroplasty: prevalence and metal ion study. J Arthroplasty. 2011;26(4):511-8.

18. Bosker BH, Ettema HB, Boomsma MF, Kollen BJ, Maas M, Verheyen CCPM. High incidence of pseudotumour formation after large-diameter metal-onmetal total hip replacement. J Bone Joint Surg Br. 2012. https://doi.org/10. 1302/0301-620X.94B6.28373.

19. Sutphen SA, MacLaughlin LH, Madsen AA, Russell JH, McShane MA. Prevalence of pseudotumor in patients after Metal-On-Metal HipArthroplasty evaluated with metal lon analysis and MARS-MRI. J Arthroplasty. 2016;13:260-3. https://doi.org/10.1016/j.arth.2015.07.011.

20. Kleeman LT, Goltz D, Seyler TM, Mammarappallil JG, Attarian DE, Wellman SS, Bolognesi MP. Association between pseudotumor formation and patient factorsin metal-on-metal total hip arthroplasty population. J Arthroplasty. 2018; 33:259-64. https://doi.org/10.1016/j.arth.2018.03.039.

21. Wynn-Jones H, Macnair R, Wimhurst J, Chirodian N, Derbyshire B, Toms A, Cahir J. Silent soft tissue pathology is common with a modern metal-onmetal hip arthroplasty. Acta Orthop. 2011. https://doi.org/10.3109/17453674 2011.579518.

22. Malek IA, King A, Sharma H, Malek S, Lyons K, Jones S, John A. The sensitivity, specificity and predictive values of raised plasma metal ion levels 
in the diagnosis of adverse reaction to metal debris in symptomatic patients with a metal-on-metal arthroplasty of the hip. J Bone Joint Surg Br. 2012. https://doi.org/10.1302/0301-620X.94B8.27626.

23. Reito A, Lainiala O, Elo P, Eskelinen A. Prevalence of failure due to adverse reaction to metal debris in modern, medium and large diameter metal-onmetal hip replacements - the effect of novel screening methods: systematic review and Metaregression analysis. PLoS One. 2016. https://doi.org/10. 1371/journal.pone.0147872.

24. Hart A, Satchithananda K, Liddle A, Sabah S, McRobbie D, Henckel J, Cobb J, Skinner J, Mitchell A. Pseudotumors in association with well-functioning metal-on-metal hip prostheses. J Bone Joint Surg. 2012. https://doi.org/10. 2106/JBJS.J.01508.

25. Lu M, Zhou Y, Du H, Zhang J, Liu J. Reliability and validity of measuring acetabular component orientation by plain anteroposterior radiographs. Clin Orthop Relat Res. 2013. https://doi.org/10.1007/s11999-013-3021-8.

26. Woo R, Morrey B. Dislocations after total hip arthroplasty. J Bone Joint Surg. 1982;64(9):1295-306.

27. Younger TI, Bradford MS, Magnus RE, Paprosky WG. Extended proximal femoral osteotomy. A new technique for femoral revision arthroplasty. J Arthroplasty. 1995;10(3):329-38.

28. Lewinnek G, Lewis J, Tarr R, Compere C, Zimmerman J. Dislocations after total hip-replacement arthroplasties. J Bone Joint Surg. 1978;60(2):217-20.

29. Brown SA, Zhang K, Merritt K, Payer JH. In vivo transport and excretion of corrosion products from accelerated anodic corrosion of porous coated F75 alloy. J Biomed Mater Res. 1993. https://doi.org/10.1002/jbm.820270806.

30. Newton AW, Ranganath L, Armstrong C, Peter V, Roberts NB. Differential distribution of cobalt, chromium, and nickel between whole blood, plasma and urine in patients after metal-on-metal (MoM) hip arthroplasty. J Orthop Res. 2012. https://doi.org/10.1002/jor.22107.

31. Tauriainen TJT, Niinimäki TT, Niinimäki JL, Nousiainen TOP, Leppilahti Jl. Poor acetabular component orientation increases revision risk in metal-on-metal hip arthroplasty. J Arthroplasty. 2017;32(7):2204-7.

32. Agne MT, Underwood RJ, Kocagoz SB, MacDonald DW, Day JS, Parvizi J, Kraay MJ, Mont MA, Klein GR, Cates HE, Kurtz SM. Is there material loss at the backside taper in modular CoCr acetabular liners? Clin Orthop Relat Res. 2014. https://doi.org/10.1007/s11999-014-3982-2.

33. Merritt $K$, Crowe TD, Brown SA. Elimination of nickel, cobalt, and chromium following repeated injections of high dose metal salts. J Biomed Mater Res. 1989. https://doi.org/10.1002/jbm.820230804.

34. Reito A, Parkkinen J, Puolakka T, Pajamäki J, Eskelinen A. Diagnostic utility of joint fluid metal ion measurement for histopathological findings in metalon-metal hip replacements. BMC Musculoskelet Disord. 2015. https://doi. org/10.1186/s12891-015-0851-4.

35. Lehtovirta L, Reito A, Parkkinen J, Peräniemi S, Vepsäläinen J, Eskelinen A Association between periprosthetic tissue metal content, whole blood and synovial fluid metal ion levels and histopathological findings in patients with failed metal-on-metal hip replacement. PLoS One. 2018. https://doi org/10.1371/journal.pone.0197614.

36. Smeekes C, Schouten BJM, Nix M, Ongkiehong BF, Wolterbeek R, van der Wal BCH, Nelissen RGHH. Pseudotumor in metal-on-metal hip arthroplasty: a comparison study of three grading systems with MRI. Skeletal Radiol. 2018. https://doi.org/10.1007/s00256-018-2873-0.

37. Anderson H, Toms AP, Cahir JG, Goodwin RW, Wimhurst J, Nolan JF. Grading the severity of soft tissue changes associated with metal-on-metal hip replacements: reliability of an MR grading system. Skelet Radiol. 2011. https://doi.org/10.1007/s00256-010-1000-7.

38. Hauptfleisch J, Pandit H, Grammatopoulos G, Gill HS, Murray DW, Ostlere S. A MRI classification of periprosthetic soft tissue masses (pseudotumours) associated with metal-on-metal resurfacing hip arthroplasty. Skelet Radiol. 2012. https://doi.org/10.1007/s00256-011-1329-6.

\section{Publisher's Note}

Springer Nature remains neutral with regard to jurisdictional claims in published maps and institutional affiliations.

\section{Ready to submit your research? Choose BMC and benefit from:}

- fast, convenient online submission

- thorough peer review by experienced researchers in your field

- rapid publication on acceptance

- support for research data, including large and complex data types

- gold Open Access which fosters wider collaboration and increased citations

- maximum visibility for your research: over $100 \mathrm{M}$ website views per year

At $\mathrm{BMC}$, research is always in progress.

Learn more biomedcentral.com/submissions 